\title{
WAXES AND PLASTIC FILM IN RELATION TO THE SHELF LIFE OF YELLOW PASSION FRUIT
}

\author{
Wagner Ferreira da Mota1,3; Luiz Carlos Chamhum Salomão ${ }^{1 *}$; Paulo Roberto Cecon²; Fernando \\ Luiz Finger ${ }^{1}$ \\ ${ }^{1}$ Depto. de Fitotecnia - UFV - CEP: $36571-000$ - Viçosa, MG. \\ ${ }^{2}$ Depto. de Informática - UFV. \\ ${ }^{3}$ CAPES Fellow. \\ *Corresponding author <Isalomao@ufv.br>
}

\begin{abstract}
The high perishability of the yellow passion fruit ( Passiflora edulis $f$. flavicarpa) reduces its postharvest conservation and availability, mainly for in natura consumption. These losses of quality and commercial value occur due to the high respiration and loss of water. This work aimed to evaluate the influence of a modified atmosphere - wax emulsions and plastic film - on the shelf life of the yellow passion fruit. Plastic film (Cryovac D-955, 15 $\mu \mathrm{m}$ thickness) reduced fresh weight loss and fruit wilting, kept higher fruit and rind weight and higher pulp osmotic potential over the storage period. However, it was not efficient in the control of rottenness. Sparcitrus wax (22-23\% polyethylene/maleyc resin) caused injury to the fruit, high fruit weight losses and wilting and resulted in lower pulp osmotic potential; this wax lead to a higher concentration of acid and a lower relation of soluble solids/acidity. Among the tested waxes, Fruit Wax (18-21\% carnauba wax) was the best, promoting reduced weight loss, wilting and rottenness.
\end{abstract}

Key words: Passiflora edulis f. flavicarpa, water loss, modified atmosphere

\section{CERAS E EMBALAGEM PLÁSTICA NA CONSERVAÇÃO PÓS-COLHEITA DO MARACUJÁ-AMARELO}

\begin{abstract}
RESUMO: O período de comercialização do maracujá-amarelo ( Passiflora edulis f. flavicarpa), principalmente para consumo "in natura", é reduzido devido a rápida modificação de sua aparência. Esta perda de qualidade e de valor comercial, ocorre em razão da intensa atividade respiratória e da elevada perda de água. Este trabalho objetivou avaliar a influência do uso da atmosfera modificada, por meio do uso de emulsões de cera e filme plástico na vida de prateleira do maracujá-amarelo. O filme plástico (Cryovac D-955) foi o mais eficiente em reduzir a perda de matéria fresca e o murchamento dos frutos, além de manter maior massa de matéria fresca da casca e do fruto e maior potencial osmótico da polpa ao longo do período de armazenamento. Entretanto, não foi eficiente no controle de podridões. O emprego da cera Sparcitrus (22-23\% polietileno/resina maleica, solvente orgânico) condicionou injúria nos frutos, elevada perda de matéria fresca, murchamento e menor potencial osmótico da polpa; além disso, essa cera manteve maior concentração de ácido e menor relação sólidos solúveis totais/acidez titulável. Dentre as ceras, destacou-se a Fruit Wax (18-21\% cera carnaúba, solvente água), com menores perdas de matéria fresca, murchamento e podridões dos frutos.

Palavras-chave: Passiflora edulis f. flavicarpa, perda de água, atmosfera modificada
\end{abstract}

\section{INTRODUCTION}

The commercializing period of yellow passion fruits for consumption in natura (fresh) is reduced due to rapid modifications in their appearance, resulting from intense shriveling (Araújo et al., 1974; Cereda et al., 1976; Enamorado et al., 1995; Scheer, 1994). This loss in quality, and consequently in commercial value, takes place because of intense respiratory activity and significant loss of water (Castro, 1994; Lownds et al., 1993; Scheer, 1994), which depend on differences in temperature and relative humidity, and on the water vapor pressure differential between the atmosphere and the product (Scheer, 1994).

When the water vapor pressure in the fruit is higher than in the environment the fruit loses water. One of the mechanisms utilized to reduce water loss and increase the storage period of passion fruits is the use of a modified atmosphere by means of adequate plastic packaging or hydrophobic additives, on the fruit surface, such as waxes, thus reducing transpiration and respiration rates (Fonseca et al., 2000; Silva et al., 1999; Castro, 1994; Martim-Polo et al., 1992).

Fruits and vegetables coated with wax look better and exhibit improved shriveling control (McGuire \& Hullman, 1995; Smith et al., 1987). Plastic films and waxes increase post-harvest life because fruit respiration occurs inside the coating and consequently there is a reduction in the concentration of $\mathrm{O}_{2}$ and an increase in $\mathrm{CO}_{2}$, and an atmosphere with high relative humidity is formed, thus reducing water loss by transpiration (Fonseca et al., 2000; McGuire \& Hullman, 1995; Moleyar \& Narasimham, 1994). Low $\mathrm{O}_{2}$ and/or high $\mathrm{CO}_{2}$ concentrations, in addition to reducing the respiratory rate and, consequently, the substrate (starch, sugars, organic acids) utilization rate, also reduce ethylene production (Kader, 1995; Lazan \& Ali, 1993). 
Usually, formulations containing petroleum or plant-based mixtures can be found in the market, and these are utilized as sprays or immersions. Commercial emulsions contain approximately 20 to $25 \%$ solids, and since the treatment requires 6 to $10 \%$ solids, they are diluted in one or two parts of water, adding a wetting agent to break the surface tension of the particles on the fruit surface, improving their adhesiveness to the fruit (Watkins, 1971).

Hydrophilic emulsions based on cellulose derivatives are specifically formulated to act on the reduction of $\mathrm{O}_{2}, \mathrm{CO}_{2}$ and water diffusion, and thus delay ripening and decrease the loss of fruit mass, in spite of their reduced effect on water vapor exchange (McGuire \& Hullman, 1995). Carnauba wax is regularly used in emulsions, but it is not particularly effective in preventing water loss, and it is also more permeable to $\mathrm{O}_{2}, \mathrm{CO}_{2}$ and ethylene. For these reasons, many formulations include paraffin, which is more impermeable (Smith et al., 1987).

Polymeric films are utilized for fruit, vegetable and flower storage in modified and controlled atmospheres (Fonseca et al., 2000; Silva et al., 1999). These films consist of long chains of repetitive units called monomers, linked to each other by covalent bonds, and they can be homopolymers or heteropolymers, whether they are formed by the same monomer or by different monomers in the chain, respectively (Robertson, 1993).

Normally, high and low density polyethylene, as well as polypropylene and PVC films of several gauges, are utilized. The internal atmosphere composition will depend upon the characteristics of the packaging material and on the gas consumption or release velocity by the packaged product. The ideal packaging is one that allows a concentration of $\mathrm{O}_{2}$ sufficiently low to delay respiration, yet sufficiently high so as not to condition anaerobic respiration and still maintain relative humidity levels high enough to keep the high water vapor pressure controlling water loss and, consequently, mass loss by the fruit (Chitarra \& Chitarra, 1990; Silva et al., 1999; Fonseca et al., 2000).

Both melted paraffin and polyethylene films have been successfully tested to extend the post-harvest life of yellow passion fruits, contributing to reduce shriveling and maintain the internal quality of the product (Gama et al., 1991).

This project aim to extend the postharvest conservation period of yellow passion fruits for consumption in natura, by reducing water loss with the utilization of different wax emulsions and a plastic film.

\section{MATERIAL AND METHODS}

Yellow passion fruits (Passiflora edulis Sims $t$. flavicarpa Deg.) were harvested in the field, when presenting 80 to $100 \%$ of the rind with a yellow coloration, in a commercial orchard of Coimbra, MG, Brazil, located at the following geographic coordinates: $20^{\circ} 50^{\prime} 30^{\prime \prime} \mathrm{S}$ and $42^{\circ} 48^{\prime} 30^{\prime \prime} \mathrm{W}$ and $716 \mathrm{~m}$ altitude. After harvesting, the fruits were placed inside plastic boxes and transported to the Post-Harvest Laboratory, where they were selected and washed in pure water and then treated with sodium hypochlorite solutions at $1 \%$ and benomyl at $0.5 \mathrm{~g} \mathrm{~L}^{-1}$.

The treatments were: individual immersion of fruits in water (control), or Fruit Wax-type waxes (18-21\% carnauba wax, solvent and water) diluted to a 1:4 rate in water, Sunny Side Citrus (maleic resin and organic solvent) diluted to a $1: 1$ rate and Sparcitrus $(22-23 \%$ polyethylene/maleic resin, solvent and water) without dilution, or packaging with polyolefin thermo-shrink plastic film (Cryovac D-955, $15 \mu \mathrm{m}$ thickness). The fruits were placed, in groups of four, in polystyrene trays $(140 \times 140$ $\mathrm{mm}$ ) and stored at room temperature and relative humidity $\left(20-25^{\circ} \mathrm{C}, 70-85 \% \mathrm{RH}\right)$. The experiment was organized in a split-plot design, with five treatments per mainplot and eight or nine sampling periods per subplot, with four replicates, in a random-block experimental design.

The analyses were carried out beginning on the experimental setup date (day 0 ) and then at three-day intervals totaling 21 or 24 days, for the following traits: fruit, rind and pulp fresh matter weight; fruit fresh matter loss percentage; shrinkage index, by means of a rating scale from 0 to 5 , relating volume loss to the visuallyestablished shriveling degree of the fruits, where: $0=0 \%$, $1=3 \%, 2=6 \%, 3=9 \%, 4=12 \%$ and $5=15 \%$ volume loss; rot incidence (diseases or physiological disorders) on the rind by counting fruits with the presence or absence of rots, and later calculating the percentage of deteriorated fruits per plot; rind and pulp percentage; pulp/rind ratio; relative water content in the rind by means of methodology described by Catsky (1974), utilizing the equation cited by Weatherley (1950); concentration of total soluble solids and total titratable acidity utilizing methodology recommended by AOAC (1975); and total soluble solids/total titratable acidity ratio in the juice; pulp osmotic potential of the sample, based on the principle of cryoscopy, and ascorbic acid content in the juice, according to the technique recommended by the Instituto Adolfo Lutz (1985).

The data were interpreted by means of analysis of variance and regression. The means were compared by the Tukey test at $5 \%$, and the regression models were chosen based on the significance of the regression coefficients, utilizing the Student $t$ test at $5 \%$, and on the coefficients of determination. The treatment $x$ storage period interaction effect was partitioned, and the periods in each treatment were studied by means of regression while the treatments in each storage period were studied by means of the Tukey test at $5 \%$. When isolated effects for treatments or storage periods occurred, they were analyzed by using the general means for the treatment and for each storage period by means of the Tukey test and regression analysis, respectively. 


\section{RESULTS AND DISCUSSION}

Fruits packaged in polyolefin film (FPT) maintained higher fruit (FM) and rind (RM) fresh matter masses for 21 days after harvesting, with means of 164.7 $\mathrm{g}$ and $90.1 \mathrm{~g}$, respectively, despite the fact that no significant differences occurred relative to the Sunny Side Citrus wax (SSC) (Table 1). In addition, the fruits packaged in plastic film (FPT) also presented higher relative water content (RWC) in the rind, even though they did not differ from the waxes Fruit Wax (FWX) and Sparcitrus (SPC), with average levels around $61.0 \%$. Control fruits were those that maintained the lowest fresh matter masses in fruit and rind. A similar result was observed for fresh matter loss percentage and shrinkage index of fruits (Figure 1), verifying that, as the days under storage increased, a significant difference was gradually observed between fruits coated with plastic film (FPT) and the others. This difference was intensified in time, with fruits packaged in polyolefin film (FPT) shrinking less and losing less mass than those immersed in wax or in water (control) (Figure 1). This greater efficiency occurred because a saturated humidity environment was formed inside the package, due to its lower permeability to water vapor, as compared to the waxes, with a reduction in water vapor pressure gradient between the fruits and the internal atmosphere of the packaging and, consequently, reducing fruit transpiration. Probably, saturation in $\mathrm{CO}_{2}$ and a reduction in $\mathrm{O}_{2}$ content in the microenvironment also occurred along time for the storage period, decreasing and controlling respiration.

No differences were verified between treatments with respect to the fresh matter mass in the pulp (FMP) and the pulp/rind ratio (PRR) (Table 1).

The fresh matter loss percentage and the shrinkage index did not differ between waxed fruits and control fruits (CON) in the beginning of the storage period, however, from that point forward, fruits treated with Sparcitrus wax (SPC) began to lose more mass and to shrivel more rapidly (Figure 1). This occurred because the Sparcitrus wax causes plant toxicity effects that probably affected the cuticle or epidermis structure in the fruit, causing the fruits to shrink more intensely, since on the third day after setting up the experiment it was already possible to observe depressed brown-colored punctuations on fruit skins. On the day the experiment was set up (day 0) passion fruits treated with Sparcitrus wax lost their typical coloration, going from "gold-yellow", characteristic for the species, to brown, a color that persisted during the entire storage period. The plant toxicity could be due to the active principle in Sparcitrus wax, or to the utilization of the product in a high concentration, since it was applied without dilution, according to the manufacturer's recommendation.

The fresh matter loss percentage, shrinkage index and osmotic potential of fruits increased along the storage period in all treatments (Figure 1).

The polyolefin plastic film (FPT) was the most efficient in reducing the fresh matter loss percentage and the shrinkage index, as compared to waxed fruits and the control, because after 24 days of storage, this loss was only $0.96 \%$, and for the shrinkage index it was only 0.24 (less than $3 \%$ volume loss), with fruits maintaining a more turgidous aspect and better marketing conditions during the storage period (Figure 1). The fact that fruits packaged in plastic film remained more turgid also evidenced that the loss of water occurred especially from the skin to the environment.

The other treatments, immersion of fruits in water (CON), in Sunny Side Citrus wax (SSC) or in Fruit Wax (FWX), had an intermediary efficiency in reducing the fresh matter loss percentage and in controlling the shrinkage index. Even though the waxes reduced gaseous exchanges, waxes used in the experiment were not as effective as the plastic film (FPT) in reducing fresh matter loss percent and shrinking. Maybe this lower efficiency is due to the reduced thickness of the wax layer, as verified by Gama et al. (1991) which, when using Autocitrol wax, did not observe water loss control in passion fruits, losing $16.65 \%$, on average, after 42 days of storage at $6^{\circ} \mathrm{C}$.

Among the waxes, Fruit Wax (FWX) was the most efficient in controlling the fresh matter loss percentage and shrinkage index (Figure 1). Watkins (1971) and Smith et al. (1987) stated that carnaubabased wax is not effective in preventing water loss.

Table 1 - Fresh matter masses in fruit (FM) and rind (RM), relative water content in rind (RWC), fresh matter mass in pulp (FMP), and pulp/rind ratio (PRR) of fruits stored under room conditions, during 21 days, after immersion in water (CON) and in waxes Fruit Wax (FWX), Sparcitrus (SPC) and Sunny Side Citrus (SSC) or with polyolefin film coating (FPT).

\begin{tabular}{llllll}
\hline Treatment & FM & RM & FMP & RWC & PRR \\
\hline & $144.75 \mathrm{c}$ & $77.14 \mathrm{c}$ & $67.61 \mathrm{a}$ & $57.25 \mathrm{c}$ & $0.88 \mathrm{a}$ \\
CON & $153.02 \mathrm{bc}$ & $84.20 \mathrm{ab}$ & $68.82 \mathrm{a}$ & $60.08 \mathrm{ab}$ & $0.83 \mathrm{a}$ \\
FWX & $148.79 \mathrm{bc}$ & $79.63 \mathrm{bc}$ & $69.16 \mathrm{a}$ & $61.02 \mathrm{a}$ & $0.88 \mathrm{a}$ \\
SPC & $157.12 \mathrm{ab}$ & $83.87 \mathrm{abc}$ & $73.24 \mathrm{a}$ & $57.82 \mathrm{bc}$ & $0.88 \mathrm{a}$ \\
SSC & $164.77 \mathrm{a}$ & $90.12 \mathrm{a}$ & $74.64 \mathrm{a}$ & $61.64 \mathrm{a}$ & $0.83 \mathrm{a}$ \\
FPT & &
\end{tabular}

Means followed by at least one common letter, in the column, do not differ by the Tukey test at $5 \%$. 
Salazar \& Torres (1977) reported a fresh matter loss of $31.45 \%$ in non-packaged yellow passion fruits stored at $23^{\circ} \mathrm{C}$ and $76 \%$ relative humidity, for 14 days. In fruits packaged with polyethylene without perforations, however, the fresh matter loss, for the same period, was only $0.85 \%$. In this project, 15 days after harvest, fresh matter loss of $10.48 \%$ were verified in non-packaged fruits, and of $0.63 \%$, on average, in fruits packaged with polyolefin film (FPT). This discrepancy of results between treatments was possibly due to the fact that the fruits in this project were harvested in the field, and they could more resistant to senescence, or even because of the variability inherent to the species.

The increase in osmotic potential (less negative), as observed in Figure 1, provided evidence, in all treatments, that the concentration of osmotically active
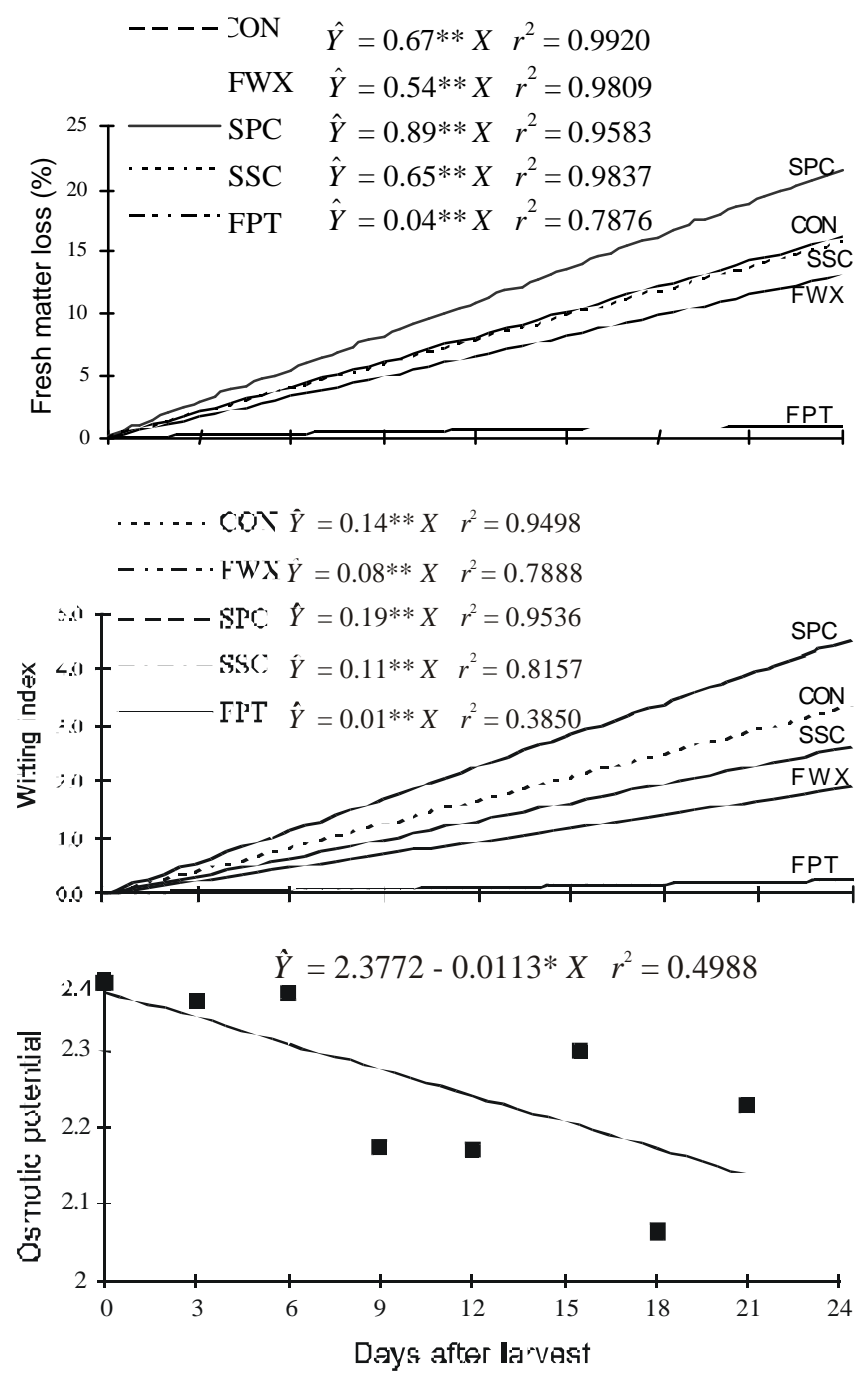

${ }^{* *} \mathrm{e}^{*}=1$ e $5 \%$ by test "t", respectively

Figure 1 - Estimates of fresh matter loss percent, shrinkage index and osmotic potential of the pulp of passion fruits stored under room conditions, as a function of days after harvesting, polyolefin film coating (FPT) or immersion in water $(\mathrm{CON})$ or in the waxes Fruit Wax (FWX), Sunny Side Citrus (SSC) and Sparcitrus (SPC). solids in the pulp decreased along the storage period. Since the consumption of solids in the respiratory process is very low (Araújo et al., 1974; Sjostrom \& Rosa, 1978; Arjona \& Matta, 1992), it is more likely that a migration of water occurred from the rind to the pulp.

The mean fresh matter masses in the fruit and in the rind decreased quadratic and linearly, respectively, along the storage period, while the fresh matter mass in the pulp obtained a cubic form of response, with an initial increasing stage, then an intermediate reduction stage, and a final stage which tended to remain constant (Figure 2). The increase in fresh matter mass in the pulp up to the ninth day indicates a flow of water from the rind to the pulp, since in the same period, the fresh matter mass in the rind was more rapidly reduced than the fresh matter mass in the fruit. Enamorado et al. (1995) obtained

Fruit.

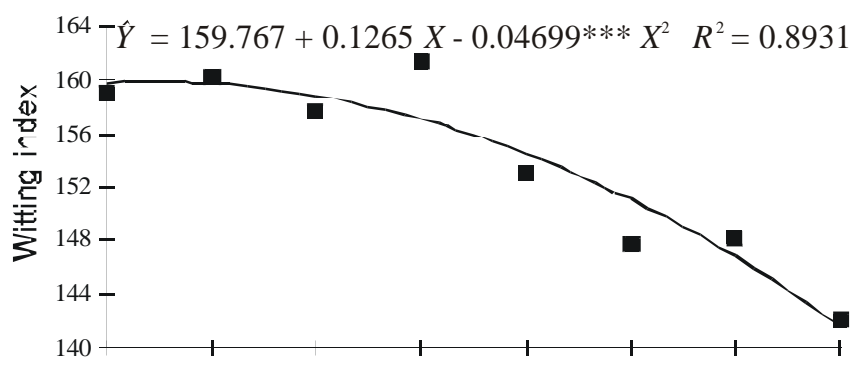

Rind
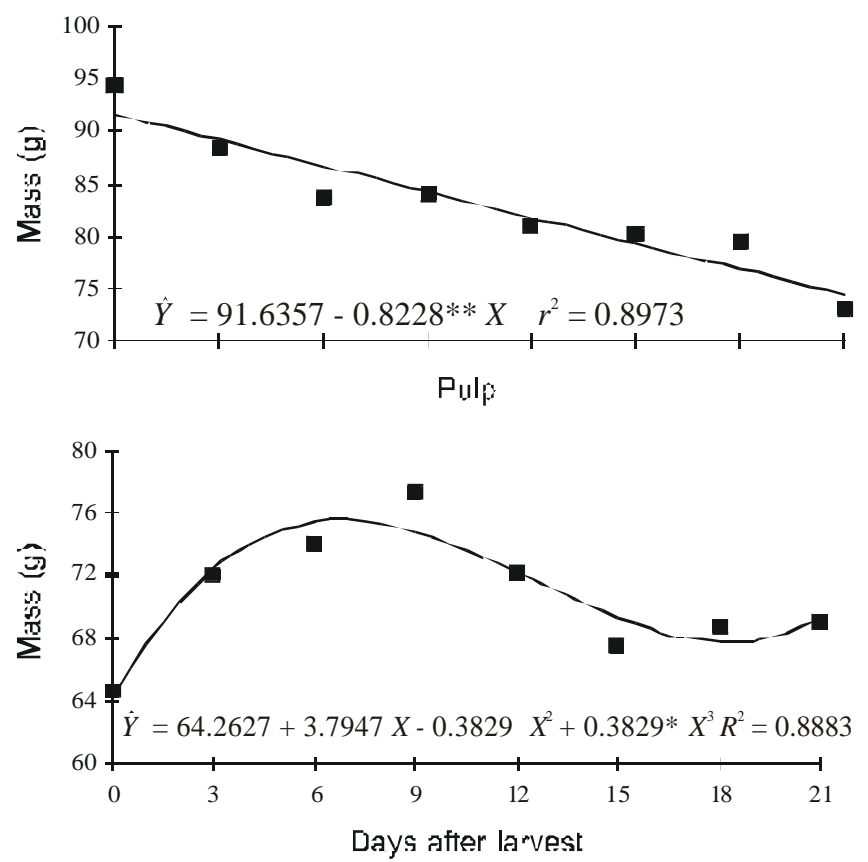

** $,{ }^{*} e^{* * *}=1,5$ e $20 \%$ by test "t", respectively.

Figure 2 - Estimates of fresh matter masses, in rind and pulp of fruits, as a function of days after harvesting and of storage under room conditions, after coating with polyolefin film or immersion in water or in the waxes Fruit Wax, Sunny Side Citrus and Sparcitrus. 
similar results. Gama et al. (1991) verified, in a percentage scale, after 42 days, a reduction in rind mass and an increase in mass loss in the fruits, which occurred due to dehydration; as a consequence, there was an increase in the volume of juice in the same period.

The flow of water from the rind to the pulp became more evident when there was a rapid reduction in the percentage rind and in the relative water content up to the sixth day, as well as a rapid increase in percentage pulp and in pulp/rind ratio during the same period (Figure 3).

From the ninth storage day on, both the rind and the pulp began to lose water to the environment, which was confirmed by the stabilization of the pulp/rind ratio and by the increase in fruit fresh matter loss rate (Figure 2). Supporting this hypothesis, a practically constant maintenance of rind and pulp percentages was observed after the sixth day of storage as well as the relative water content in the rind beginning in the third day (Figure 3).
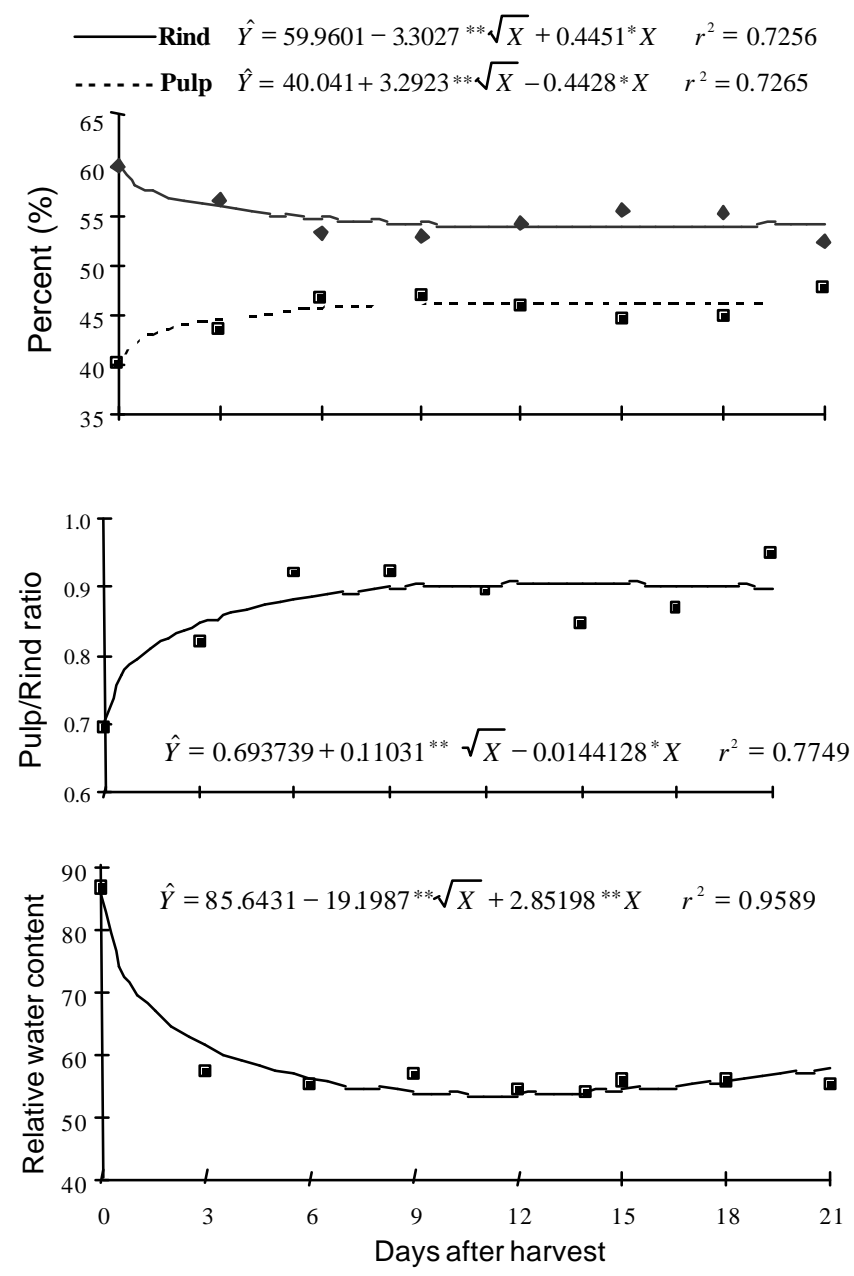

${ }^{* *} e^{*}=1$ e $5 \%$ by test "t", respectively.

Figure 3 - Estimates of rind and pulp percentages, pulp/rind ratio and relative water content in the rind of fruits as a function of days after harvesting and of storage under room conditions, after coating with polyolefin film or immersion in water or in the waxes Fruit Wax, Sunny Side Citrus and Sparcitrus.
Such fact indicates that, a few days after harvesting, the water loss in the rind is verified predominantly to the environment and, at the same time that the rind undergoes water deficit, it is then replaced by the pulp. Finger (1985) verified an increase in relative water content in banana pulp and a concurrent reduction in the skin, indicating that water flowed from the skin to the pulp, a fact that was enhanced as fruit maturation progressed.

In a general way there was no difference between treatments with regard to total soluble solids and to ascorbic acid content. Fruits immersed in Sparcitrus wax (SPC) sustained a higher concentration of acids, and a lower total soluble solids ratio/titratable acidity, as compared to fruits submitted to other types of coating, which did not show differences among themselves (Table 2). The Sparcitrus wax might have promoted the acidification of the fruits, by producing citric acid catalyzed by the enzyme phosphoenolpyruvate (PEP) carboxylase as the excess $\mathrm{CO}_{2}$ produced was fixed, or might also have delayed some of the regular maturation processes, through injury imposed to the fruits.

A linear reduction in total soluble solids and titratable acidity was verified along the storage period (Figure 4). The decreases in total soluble solids and titratable acidity were also observed in yellow passion fruits by Araújo et al. (1974), Sjostrom \& Rosa (1978) and Enamorado et al. (1995), who ascribed these decreases to the participation of these compounds as respiratory metabolites during the maturation process. However, it is possible also that a reduction in the concentration of soluble solids occurred due to water migration from the rind to the pulp.
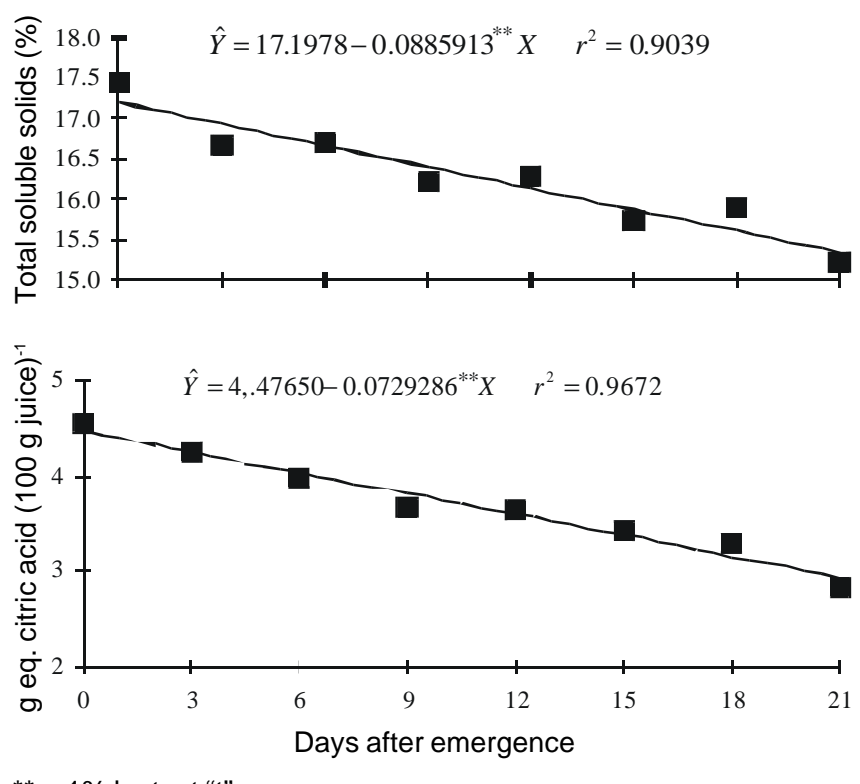

${ }^{* *}=1 \%$ by test " $\mathrm{t}$ ".

Figure 4 - Estimate of total soluble solids content ('Brix) and total titratable acidity in the juice of fruits, as a function of days after harvesting and of storage under room conditions, after coating with polyolefin film or immersion in water or in the waxes Fruit Wax, Sunny Side Citrus and Sparcitrus. 
Table 2 - Values of total soluble solids (TSS), titratable acidity (TTA), total soluble solids/titratable acidity (SSTA) ratio and ascorbic acid (AA) of fruits stored under room conditions, during 21 days, after immersion in water (CON) or in the waxes Fruit Wax (FWX), Sparcitrus (SPC) and Sunny Side Citrus (SSC) or with polyolefin film coating (FPT).

\begin{tabular}{lcccc}
\hline Tratamento & TSS & TTA & SSTA & AA \\
\hline CON & ${ }^{\circ}$ Brix & g.eq.cit.ac. $/ 100 \mathrm{~g}$ & & $\mathrm{mg} / 100 \mathrm{~mL}$ \\
FWX & $16.21 \mathrm{a}$ & $3.55 \mathrm{~b}$ & $4.74 \mathrm{a}$ & $36.87 \mathrm{a}$ \\
SPC & $16.25 \mathrm{a}$ & $3.57 \mathrm{~b}$ & $4.71 \mathrm{a}$ & $37.00 \mathrm{a}$ \\
SSC & $16.04 \mathrm{a}$ & $4.18 \mathrm{a}$ & $3.86 \mathrm{~b}$ & $34.80 \mathrm{a}$ \\
FPT & $16.33 \mathrm{a}$ & $3.60 \mathrm{~b}$ & $4.63 \mathrm{a}$ & $35.35 \mathrm{a}$ \\
\hline
\end{tabular}

Means followed by at least one common letter, in the column, do not differ by the Tukey test at $5 \%$.

The total soluble solids/titratable acidity ratio and the ascorbic acid content increased linearly along the storage period (Figure 5). This increase in total soluble solids/titratable acidity ratio was also observed by Gama et al. (1991) and Rojas \& Medina (1996) during maturation of yellow passion fruits.

The increase in ascorbic acid content verified during storage was probably due to the fact that fruits stored under room conditions were undergoing a senescence process, when synthesis of ascorbic acid in small amounts and reduced utilization of this acid occurred, because, according to Mapson (1970), ascorbic acid is particularly abundant in tissues that present high metabolic activity.

For tissues at the maturation or senescence stages, however, a reduced synthesis of ascorbic acid occurs, as well as its utilization decreases (Chinoy, 1978).

The increases in ascorbic acid content that were found contradict the tendency of reduction of organic acid contents in the juice, previously discussed, and also contradicts results obtained by Collazos et al. (1984). However, these authors evaluated physiologically mature fruits, but when the rind was still green, i.e., at a high metabolic activity, a condition in which ascorbic acid is abundant, but its utilization is high, leading to a reduction in concentration.

Figure 6 provides evidence of an increase in the incidence of fruit rots in all treatments during the storage period, and differences in intensity and in the onset of occurrence were observed between fruits in the treatments.

No references were found that would show the evolution of rots along the storage period in yellow passion fruits. Gama et al. (1991) observed the uprising of pathogenic agents in the genera Fusarium sp., Cladosporium sp., Alternariasp. and Penicillium sp. along the storage period; they did not provide, however, a quantitative study of this.

The Sparcitrus wax (SPC) was the most efficient in reducing the percentage of rots and in promoting a delay in their occurrence, since rots in this treatment began on the 15th day after harvesting; by the end of 24 days there were $25 \%$ of the fruits affected (Figure 6 ). Notwithstanding, it is possible that the injuries caused by
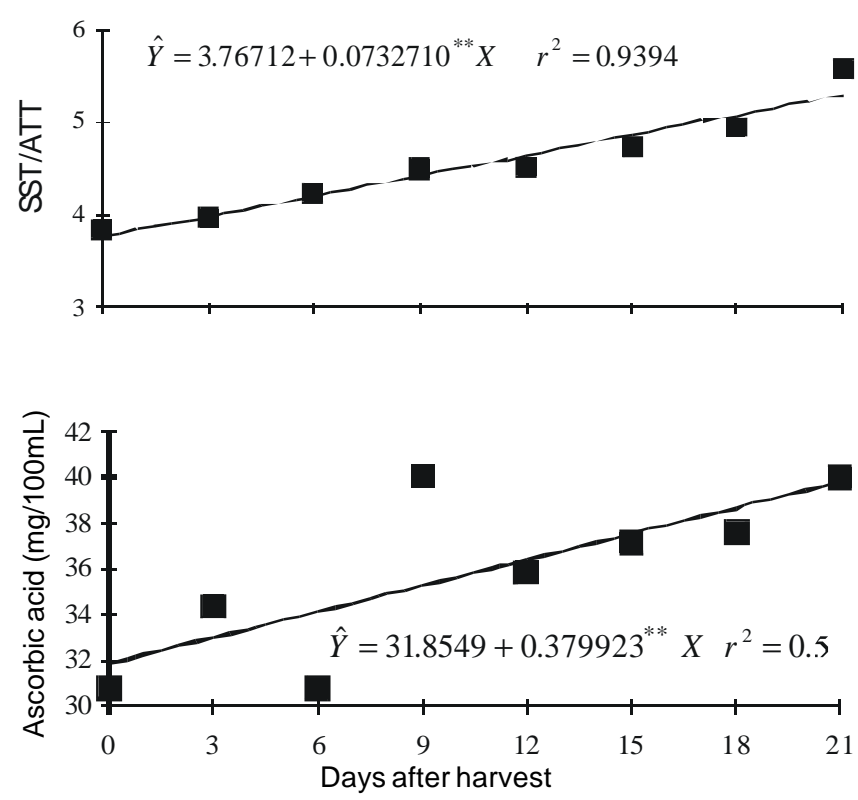

${ }^{* *} \mathrm{e}^{*}=1 \mathrm{e} 5 \%$ by "t", respectively.

Figure 5 - Estimate of total soluble solids (TSS)/total titratable acidity (TTA) ratio and ascorbic acid content in fruits stored underroom conditions, as a function of days after harvesting, polyolefin film coating or immersion in water or in the waxes Fruit Wax, Sunny Side Citrus or Sparcitrus.

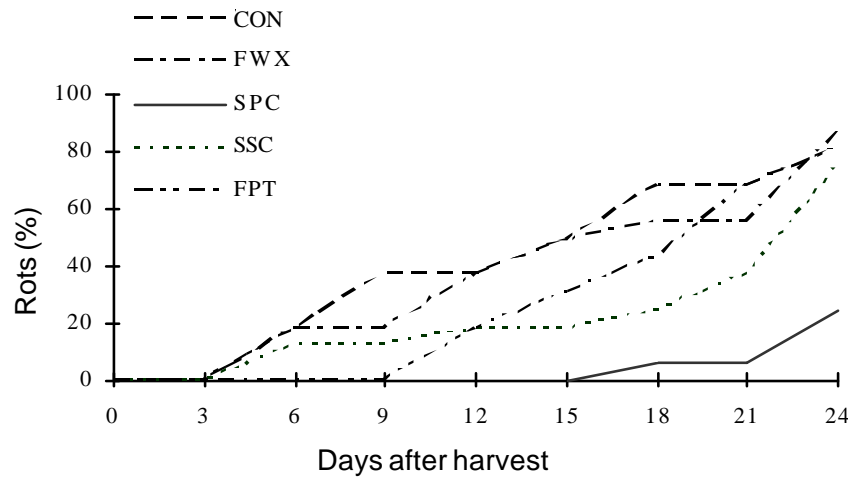

Figure 6 - Percentage of rots in fruits stored under room conditions, as a function of time after harvesting and coating with polyolefin film (FPT) or immersion in water (CON) or in the waxes Fruit Wax (FWX), Sunny Side Citrus (SSC) or Sparcitrus (SPC). 
this wax masked the symptoms and made rot observation more difficult. The least efficient treatments were, in turn, the control (CON) and the Fruit Wax treatment (FWX), because the occurrence of rots began on the third day and was more intense along the storage period, with almost-linear increases, producing, by the end of a 24day period after harvesting, $81.2 \%$ and $87.5 \%$ of rots, respectively. This also demonstrates that treating the fruits with sodium hypochlorite and benomyl was not efficient to control rots.

The use of Sunny Side Citrus wax (SSC) resulted in an intermediate control of rot intensity, as compared to the control (CON), and to waxes Fruit Wax (FWX) and Sparcitrus (SPC), since it maintained rots at low levels $(<20 \%)$ up to the 15th day after harvest, resulting, at the end of the storage period, in $75 \%$ rots on fruits.

The polyolefin plastic packaging (FPT) delayed the onset of rot occurrence up to the ninth day after harvesting; from then on, rot occurrence was accelerated, reaching $81.2 \%$ of the packaged fruits by the end of the storage period.

\section{CONCLUSIONS}

The polyolefin packaging was the most efficient way of extending the post-harvest life in yellow passion fruits, reducing the fresh matter loss percentage and shrinkage, maintaining the fruits in good condition for consumption for a longer period.

Among the waxes, Fruit Wax provided the best preservation of the original characteristics of the fruits, maintaining them in good condition for consumption for a longer period.

\section{REFERENCES}

ARAÚJO, C.M.; GAVA, A.J.; ROBBS, P.G.; NEVES, J.F.; MAIA, P.C.B. Características industriais do maracujá (Passiflora edulis var. flavicarpa) e maturação do fruto. Pesquisa Agropecuária Brasileira, v.9, p.65-69, 1974.

ARJONA, H.E.; MATTA, F.B. Postharvest quality of passion fruit as influenced by harvest time and ethylene treatment. HortScience, v.26, p.1297-1298, 1992.

ASSOCIATION OF OFFICIAL AGRICULTURAL CHEMISTS - AOAC. Official methods of analysis of the Association of Agricultural Analytical Chemistry. Washington D.C., 1975. 1094p.

CASTRO, J.V. de Matéria prima. In: INSTITUTO DE TECNOLOGIA DE ALIMENTOS. Maracujá. Campinas, 1994. 267p. (Série Frutas Tropicais)

CATSKY, J. Water content. In: SLAVIK, B. (Ed.) Methods of studying plant water relations. Berlin: Springer-Verlag, 1974. p.121-31.

CEREDA, M.P.; BRASIL, M.A.M.; LIMA, U.A. Conservação do maracujá amarelo para consumo "in natura". Acta Horticulturae, n.57, p.145-150, 1976.

CHINOY, J.J. The role of ascorbic acid in growth, differentiation and metabolism of plants. The Hage: Nijhoff/Junk, 1978. 322p.

CHITARRA, M.I.F., CHITARRA, A.B. Pós-colheita de frutos e hortaliças: fisiologia e manuseio. Lavras: ESAL/FAEPE, 1990. 320p.
COLLAZOS, O.E.; BAUTISTA, A.G.; MILLÁN, B.M.; MAPURA, B.M. Efecto de bolsas de polietileno en la conservación de maracuja (Passiflora edulis var. Flavicarpa Degener), curuba ( $P$. Mollisima HBK Bailey) y tomate (Lycopersicum esculentumMiller). Acta Agronómica, v.34, p.53-59, 1984

ENAMORADO, H.E.P.; FINGER, F.L.; BARROS, R.S.; PUSCHMANN, R Development and ripening of yellow passion fruit. Journal of Horticultural Science, v.70, p.573-576, 1995.

FINGER, F.L. Efeitos da perda de água sobre a fisiologia pós-colheita de frutos de pimentão (Capsicum annum L.) e banana (Musa acuminata Colla). Viçosa, 1985. 54p. Dissertação (Mestrado) - Universidade Federal de Viçosa.

FONSECA, S.C.; OLIVEIRA, F.A.R.; LINO, I.B.M.; BRECHT, J.; CHAU, K.V. Modelling $\mathrm{O}_{2}$ and $\mathrm{CO}_{2}$ exchange for development of perforation-mediated modified atmosphere packaging. Journal of Food Engineering, v.43, p.915, 2000.

GAMA, F.S.N. da; MANICA, I.; KIST, H.G.K.; ACCORSI, M.R. Aditivos e embalagens de polietileno na conservação do maracujá amarelo armazenado em condições de refrigeração. Pesquisa Agropecuária Brasileira, v.26, p.305-310, 1991.

INSTITUTO ADOLFO LUTZ. Normas analíticas do Instituto Adolfo Lutz: métodos químicos e físicos para análises de alimentos. São Paulo, 1985. v.1, p.183.

KADER, A.A. Regulation of fruit physiology by controlled/modified atmosphere. Acta Horticulturae, n.398, p.59-67, 1995.

LAZAN, H.; ALI, Z.M. Cell wall hidrolases and their potential in the manipulation of ripening of tropical fruits. ASEAN Food Journal, v.8, p.47-53, 1993.

LOWNDS, N.K.; BANARAS, M.; BOSLAND, P.W. Relationship between postharvest water loss and physical properties of pepper fruit (Capsicum annum L.). HortScience, v.28, p.1182-1184, 1993.

MAPSON, L.W. Vitamins in fruits In: HULME, A.C. The biochemistry of fruits and their products. New York: Academic Press, 1970. v.1, p.369-384.

MARTIM-POLO, M.; MAUGUIN, C.; VOILLEY, A. Hidrophobic films and their efficiency against moisture transfer: 1 . Influence of the film preparation technique. Journal of Agriculture and Food Chemistry, v.40, p.407412, 1992.

McGUIRE, R.G.; HULLMAN, G.U. Coating guavas with cellulose or carnaubabased emulsions interferes with postharvest ripening. HortScience, v.30, p.294-295, 1995.

MOLEYAR, V.; NARASIMHAM, P. Modified atmosphere packaging of vegetables: an appraisal. Journal of Food Science and Technology, v.31, p.267-278, 1994.

ROBERTSON, G.L. Food Packaging. New York: Marcel Dekker, 1993. 676p.

ROJAS, G.G.; MEDINA, V.M. Mudanças bioquímicas do suco do maracujá amarelo em função da idade do fruto. Revista Brasileira de Fruticultura, v.18, p.75-83, 1996

SALAZAR, C.R.; TORRES, M.R. Almacenamiento de frutos de maracujá (Passiflora edulis var. flavicarpa, Degener) en bolsas de polietileno. Revista ICA (Instituto Colombiano Agropecuário), v.12, p.01-11, 1977.

SCHEER, A. Reducing the water loss of horticultural and arable products during long term storage. Acta Horticulturae, n.368, p.511-522, 1994.

SILVA, F.M.; CHAU, K.V.; BRECHT, J.K.; SARGENT, S.A. Modified atmosphere packaging for mixed loads of horticultural commodities exposed to two postharvest temperatures. Postharvest Biology and Technology, v.17, p.1-9, 1999

SJOSTROM, G.; ROSA, J.F.L. Estudo sobre as características físicas composição química do maracujá amarelo Passiflora edulis f. flavicarpa Deg. cultivado no município de Entre Rios, Bahia. In: CONGRESSO BRASILEIRO DE FRUTICULTURA, 4; Salvador, 1977 Anais. Cruz das Almas: SBF, 1978. p.265-273

SMITH, S.; GEESON, J.; STOW, J. Production of modified atmosphere in deciduous fruit by the use of films and coatings. HortScience, v.22, p.772 776, 1987.

WATKINS, J.B. Waxing fruit and vegetables. Queensland Agricultural Journal, v.97, p.533-534, 1971.

WEATHERLEY, P.E. Studies in the water relations of cotton plant. I - The field measurement of water deficits in leaves. New Phytologist; v.49, p.81-97, 1950.

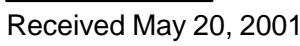

